\title{
CORRESPONDENCE
}

\section{"WHITE RINGS IN THE CORNEA"}

To the Editors of The British Journal of Ophthalmology.

DeAR SiRs,-Dr. Harry S. Gradle of Chicago, has called my attention to a short paper, contributed by him to the Amer. Jl. of Ophthal., Vol. VIII, No. 6, June, 1925, in which he recorded having seen within three years more than twenty-five cases presenting a small white ring in the cornea. From his description it would appear that the " ring" had very much the same characters as those referred to in my recent paper, but in Gradle's cases the "ring" had disappeared spontaneously within one to three days. The lack of any complaint of pain or discomfort seemed to eliminate ulceration or a foreign body as the cause.

It will be interesting to discover from further observations whether there are two groups of cases in which the lesions are similar, but in one case transient, and in the other permanent.

Yours faithfully,

A. J. Ballantyne.

GLASGOW,

July 10, 1933.

\section{OBITUARY}

\section{E. COLLIER GREEN}

WE regret to record the death, on July 30 , of Mr. Collier Green, senior ophthalmic surgeon to the Derbyshire Royal Infirmary. The son of a Yorkshire clergyman, he was born in 1858 and was trained as an architect; but as this vocation did not appeal to him he entered at St. Thomas's Hospital. Qualifying M.R.C.S. in 1881 he took an assistant house surgeon's post at Derby in the following year. After having served as house surgeon until 1887, he worked for a year at Moorfields, and in 1888 became surgeon to the newly instituted ophthalmic department at Derby.

Collier Green was a much respected and highly popular consultant in the Midlands, and held for some years the post of ophthalmic surgeon to the Burton-on-Trent Infirmary.

As a young man he was a keen mountaineer and he was well known as an amateur photographer of the first class; in this respect 
we may mention that his photographic skill was made use of by Mr. Treacher Collins, many of whose publications were enriched by his microphotographs. A charming companion, he will be much missed.

\section{NOTES}

IN connexion with the recent meeting of the Honours British Medical Association in Dublin, an honorary fellowship of the Royal Academy of Medicine in Ireland was conferred on Mr. Bishop Harman, and on Dr. C. O. Hawthorne; while Dr. Gordon Holmes received the Sc.D. of Trinity College. $\begin{array}{ll}\underset{\text { Middlemore Prize }}{1932} & \text { THIS prize has been awarded to Mr. B. W. } \\ \text { Rycroft. }\end{array}$

\section{Turberville's} Eye Lotion
THE following account of an eye lotion attributed to Turberville of Salisbury is taken, by permission of the Council of the Thoroton Society, to which body the book belongs, from the note book of Robert Marsden, Archdeacon of Nottingham (1716-1748) and Prebendary of Southwell Minster (1713-1748). Robert Marsden was of Jesus College, Cambridge, and died in August, 1748, aet. 90.

\section{Dr. Turbervill's Eye-water. Dec., 1724. From A.B.C.}

Two ounces of white Copperas, half an ounce of Camphire, 2 ounces of Bole-armoniac: Take a little earthen-pot, break ye Camphire small and lay it at the bottom of the pot: then break ye Copperas and lay over it: Set it over a gentle fire, with a paper to cover it: when it has done hissing take it off the fire: Beat it in a mortar with the Bole-armoniac, and sift it fine. Put one ounce of this powder into a bottle: then take a quart of Spring-water well warmed, and fill up the bottle : cork it, and shake it well together, and set it by ye fire 24 hours to keep it worm, in which time shake it often well together. Turn the bottle upside down to make the powder come from the bottom of it.

This water will keep-7-years. When the first water is spent, you may worm more water and keep upon ye powder.

The fire must be slow, not above a coal at a time, for fear of burning ye ingredients to ye bottom of ye pot: a Gally-pot is best 